\title{
Marketing To The Billions
}

A book review of

"The Fortune at the Bottom of the Pyramid: Eradicating Poverty Through Profits"

Review written by:

Jo Ann Pinto, Montclair State University, USA

Keywords: Economic development; poverty alleviation; micro-finance

\section{MARKETING TO THE BILLIONS}

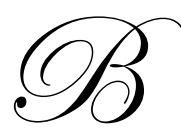

eginning with the formation of the United Nations and its various aid agencies in the post-war era, economists, government leaders and policy makers have focused tremendous energies and resources on alleviating poverty in the developing world. A recent book, entitled "The Fortune at the Bottom of the Pyramid: Eradicating Poverty Through Profits" (Wharton School Publishing, 2006; 273 pp.) takes a fresh look at an age-old problem. The book is the work of C.K. Prahalad, the Harvey C. Fruehauf Professor of Business Administration and Professor of Corporate Strategy and International Business at the University of Michigan Business School. As an added bonus, 35 minutes of on-line footage accompany the text.

In many countries past policies have fallen into one of two competing categories: market-based solutions or state ownership. One of the greatest contributions of this work is that it lays out a groundwork for a strategy that is neither exclusively market-based nor totally government run. Indeed the author argues that it is through the cooperative actions of multinationals, host country governments, NGOs and aid agencies that true prosperity can reach the billions who are at the bottom of the world's socio-economic pyramid.

The book is split into two distinct sections. In the first part, the author describes the bottom of the pyramid (BOP) market and the opportunities that exist for products and services within this market. The second part of the book contains twelve case studies which delineate BOP strategies in action. These case studies are written in collaboration with University of Michigan MBA students, which demonstrates the author's ability to engage in successful faculty-student research.

In part one, the basics of the BOP market are described. For instance, this market includes four billion participants who live on $\$ 2$ or less per day. However, taken in the aggregate, this group still has tremendous purchasing power. The key is to design products and services that meet the needs of this segment of the world's population. Products include single-serve packages which can be purchased on an as-needed basis as demand dictates. Services include the formation of micro-credit lending institutions.

The author also outlines some of the institutional factors necessary for BOP markets to function: communication, good governance, an interconnected ecosystem and the inclusion of women in the decision-making process. Of note is that the case study locales are based in emerging markets such as India, Brazil and Mexicocountries with relatively stable forms of democratic governments.

Part two examines twelve BOP case study success stories. One of the first examines microfinance, vis-à-vis the ICICI Bank of India, and its ability to help the poor start or expand small businesses. The case demonstrates that borrowers in this sector are very serious about loan repayments and represent good credit risks.

In Brazil, the case concerns a large, multi-state retailer by the name of Casas Bahias. Casas Bahias allows low-income customers to finance major purchases such as a TV or washing machine through installment purchases. Customers are showcased shopping in one of the 330 stores in the network. Specially trained salespeople evaluate credit-worthy customers. Absent the installment purchase method of payment, a large pool of consumers would be shut out of the home goods and appliances market. 
In a third case, healthcare issues are tackled in the HLL Soap story. In this case handwashing is associated with disease eradication and taken up as a public health issue. At the same time Unilever, through its Hindustan Level Limited (HLL) subsidiary sees an increases in the market for a consumer staple---soap.

All in all, the tone of this book is upbeat and leaves one feeling serious anti-poverty programs can succeed with the input of various stakeholders. The text has won praise from such distinguished individuals as Bill Gates and Madeline K. Albright. "The Fortune at the Bottom of the Pyramid" would serve as an excellent outside readings book for classes in International Business, Developmental Economics, International Marketing or Business Strategy.

\section{AUTHOR INFORMATION}

Jo Ann Pinto is currently an Associate Professor in the Department of Accounting, Law \& Taxation at Montclair State University where she has been employed since 1999. She holds a B.S. in Accounting from Virginia Polytechnic Institute and State University, an M.A. in Economics and an MBA in Accounting from Montclair State University and a Ph.D. in Accounting and Applied Economics from Rutgers University.

Her research interests are in the area of capital markets, taxation and economic development. Her publications have appeared in The CPA Journal, The Journal of Applied Business Research and the Journal of International Financial Management and Accounting, among others. Her teaching responsibilities include financial accounting, cost accounting, managerial accounting and financial statement analysis.

\section{NOTES}

